\title{
THE ROLE OF SOCIAL MEDIA IN REAL ESTATE MARKETING: A RESEARCH ON THE TRANSFORMATION OF REAL ESTATE MARKETING IN TURKEY*
}

\author{
Çiğdem AYTEKINN** \\ Seray Merve KESKÍN DEMİRLi ${ }^{* * *}$
}

\begin{abstract}
While the new media changes our daily life practices, it also causes some transformations in the field of marketing. Today it can be said that the real estate sector is also inevitably affected by this transformation and that it has developed new business models that include social media. Alexa is a website managed by amazon.com, which displays web traffic on a world and country basis. In this way, businesses can continuously monitor the visitor performance of their websites. In this study, the rankings of the Alexa web site were used to construct the sample of the research and in this way the visitor traffic was determined by the highest five real estate website in Turkey tracing techniques. On the other hand, the practices of real estate web sites to use social networks have been compared to the Alexa value ranks by examining them on specific networks and within defined metrics. Thus, it can be shown whether the real estate web site with the highest value metric has the same order in the Alexa valuation, and the role of social media in real estate marketing is evaluated within the dimensions of transformation. Research is essential since it makes an instantaneous evaluation of the circumstances and snaps a moment in the timeline.
\end{abstract}

Keywords: Social Media, Transformation, Real Estate Marketing

* Date of Submission: 20.04.2017; Date of Acceptance: 06.07.2017

Some of the research included in this study is derivated from the unpublished master project of Seray Merve Keskin Demirli

** Marmara Üniversitesi, Mühendislik Fakültesi, Öğretim Üyesi, Doç.Dr.

${ }^{* * *}$ Maltepe Üniversitesi, e-MBA Yüksek Lisans Programı 


\section{GAYRIMENKUL PAZARLAMADA SOSYAL MEDYANIN ROLÜ: TÜRKIYYE'DE GAYRIMENKUL PAZARLAMANIN DÖNÜŞÜMÜ ÜZERİNE BİR ARAŞTIRMA}

\section{Öz}

Yeni nesil iletişim ortamları günlük yaşam pratiklerimizi değiştirirken pazarlama alanında da birtakım dönüşümlere neden olmaktadır. Günümüzde gayrimenkul sektörünün de bu dönüşümden kaçınılmaz olarak etkilendiği ve sosyal medyanın dâhil olduğu yeni iş modelleri geliştirdiği söylenebilir. Alexa, amazon.com tarafından yönetilen bir web sitesi olup dünya ve ülkeler bazında web trafiğini görüntülemektedir. Böylelikle işletmeler web sitelerinin ziyaretçi performansını sürekli olarak izleyebilmektedir. Bu çalışmada araştırmanın örneklemini oluşturmada Alexa web sitesinin sıralama değerlendirmesinden faydalanılmış ve bu yolla Türkiye’de ziyaretçi trafiği en yüksek beş emlak web sitesi iz sürme tekniği ile belirlenmiştir. Diğer yandan, emlak web sitelerinin sosyal ağları kullanma pratikleri belli ağlar bazında ve tanımlanan metrikler çerçevesinde incelenerek Alexa değer sıralamaları ile karşılaştırılmıştır. Böylelikle, en yüksek değerli metriğe sahip emlak web sitesinin Alexa değerlemesinde de aynı sıraya sahip olup olmadığı ortaya konabilmiş ve gayrimenkul pazarlamada sosyal medyanın yeri dönüşümün boyutları çerçevesinde değerlendirilmiştir. Araştırma, anlık bir durum değerlemesi yapması ve buna ilişkin bir fotoğraf çekmesi bakımından önemlidir.

Anahtar Kelimeler: Sosyal Medya, Dönüşüm, Gayrimenkul Pazarlama

\section{INTRODUCTION}

Marketing is a well-developed methodological science and is constantly changing its rules according to the needs and developments taking place in and around it. To establish itself in the new era, it has begun adapting the new methods of virtues to come to terms with the new paradigms of business. The role of marketing in the development of business is intact but the way it has been executed is radically changing due to contributions made by satellite communication and extensively developed scientific devices. Social Media is best defined in the context of the previous industrial media paradigm. Traditional media such as television, newspapers, radio and magazines are in one direction static show technologies. New web technology has made it simple for anyone to create and most highly, issue their own content. A blog position, tweet or YouTube video can be twisted and viewed by millions almost for free. Advertisers don't have to reimburse publishers or distributors huge sums of money to embed their messages and they can make their own interesting content that viewers will flock to. Social media comes in many forms and the eight most popular are: Blogs, Microblogs, Social Networks, Media-Sharing Sites, Social Bookmarking and selection Sites, analysis Sites, forum and effective Worlds (Saravanakumar and Suganthalakshmi, 2012). 
Brands and customers are communicating with each other without any restriction in time, place, and medium so that old-fashioned one-way communication is changed to interactive two-way direct communication. In this way, brands and customers are working together to create new products, services, business models, and values. Meanwhile, brands can gain exposure and strengthen relationships with customers. Social media marketing is a two-way communication seeking empathy with young users, and even enforcing the familiar emotions associated with existing luxury brands to a higher age group. In addition, social media activities of brands provide an opportunity to reduce misunderstanding and prejudice toward brands, and to elevate brand value by creating a platform to exchange ideas and information among people online (Kim and Ko, 2012: 1480).

On the other hand, according to Realtors and Google, over the past decade, our world, and particularly the world of house hunters has become increasingly digital. Consumers are going online at a rapid pace to look for information to support their buying decisions. They watch "how-to" videos on YouTube, they read review sites, and they look up specific brands on search engines, and even research on the go with their smartphones and tablets (The National Association of Realtors and Google, 2012: 2).

In this study, a research was carried out in order to reveal the role of social media in real estate marketing in Turkey and the transformation of real estate marketing has been examined in this frame. It is essential since it makes an instantaneous evaluation of the circumstances and snaps a moment in the timeline.

\section{SOCIAL MEDIA MARKETING}

Social media marketing is an integral element of 21 st-century business. However, the literature on social media marketing remains fragmented and is focused on isolated issues, such as tactics for effective communication. The current research applies a qualitative, theory-building approach to develop a strategic framework that articulates four generic dimensions of strategic social media marketing (Felix et al., 2017: 118).

Social media marketing (SMM) is a two-way communication seeking empathy with young users, and even enforcing the familiar emotions associated with existing luxury brands to a higher age group. In addition, social media activities of brands provide an opportunity to reduce misunderstanding and prejudice toward brands, and to elevate brand value by creating a platform to exchange ideas and information among people online. With the increased use of SMM by luxury brands, it has become highly necessary to quantitatively analyze the effects of the social media (Kim and Ko, 2012: 1480).

Consumers are increasingly using online consumer reviews (OCRs) to learn about product quality. It is thus paramount for marketers to understand what makes OCRs helpful to 
consumers and how this evaluation affects their decisions (Filieri, 2015: 1261). Social media is best defined in the context of the previous industrial media paradigm. Traditional media such as television, newspaper, radio, and magazines, are one-way, static broadcast technologies. For instance, the magazine publisher is a large organization that distributes expensive content to consumers, while advertisers pay for the privilege of inserting their ads into that content (Dan, 2010: 1).

There are many things that social media can do for business. Developing a strategy for using it means that the firms need to think about what they want to accomplish this year and determine how social media fits into the plan. One of the benefits of a social media strategy is the fact that the available tools can customized for their particular needs. The firms can choose to concentrate their efforts on the sites that seem to offer the best return on investment, while taking a "wait and see" stand on the others (Neti, 2011:13).

Social media marketing tends to be less concrete than other online marketing efforts, such as search engine optimization (SEO) and pay per click (PPC). With SEO and PPC, it's very clear what happens: A person searches on a site such as Google, Yahoo or MSN. The site return results. The person than clicks on a result; lands on a particular website; and either performs an action, goes back to the search results, or gives up. These actions are measurable results that can show just how effective the marketing efforts were to get the person to perform the desired action or goal (Evans, 2010: 18).

Social media usage is on the rise with billions of frequent online interactions, and as such, social media marketing is a great way to connect consumers with companies and brands. Social media marketing is about listening to and sharing great content with the collective. This helps drive links, raise brand awareness, increase conversions, and kick-start conversations. This is a much more powerful tactic than the old practice of traditional advertising; the old strategies are no longer as effective (Weinberg, 2009: 17).

Figure 1 shows Paid Social Media. Facebook welcomes everyone who want to use its marketing tools with an easy-use business tool. Facebook business offers its users to raise awareness, drive demand and boost their sales. Basically, it helps marketers for social media marketing. Facebook business has different marketing tools, such as Facebook adverts, Facebook pages, Messenger, Instagram, Audience Network and Atlas (Facebook, 2017). Twitter for Business is a tool Twitter offers for marketers. Especially small or medium-sized business (SMB) is in Twitter's target. A study Twitter and Research Now prepared together "Customer Insights Study" (2016) tells that $66 \%$ of members have discovers a new SMB on Twitter. Same study also shows that $94 \%$ of customers plan to purchase form the SMBs they follow and $69 \%$ has already purchased from an SMB because of something they had seen on Twitter (Twitter, 2017). 


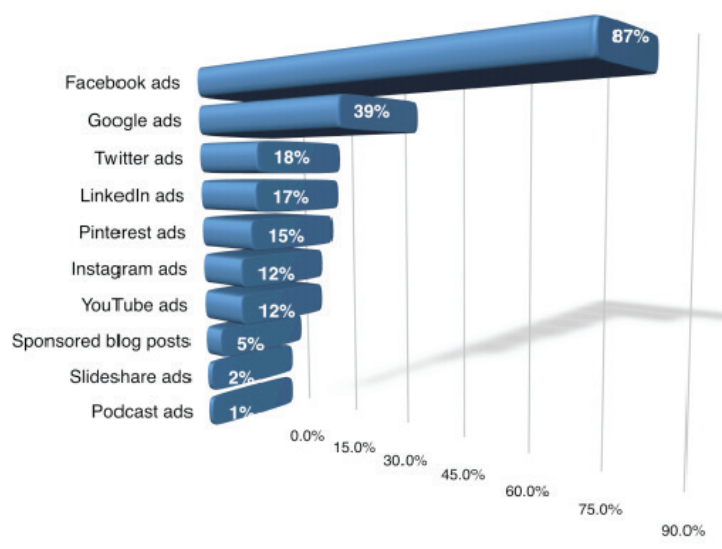

Figure 1: Paid Social Media

Source: Stelzner, 2016: 41

Figure 2 shows The Evolution of Marketing Communications. The new marketing approach is transformed from Traditional Marketing to Tradigital Marketing. With Tradigital Marketing, the tools have also been transformed. For example, "Mass and Targeted Online Media" is mentioned instead of "Mass Media". The messaging now also includes interactivity. In other words, social media plays an active role in fulfilling marketing objectives.
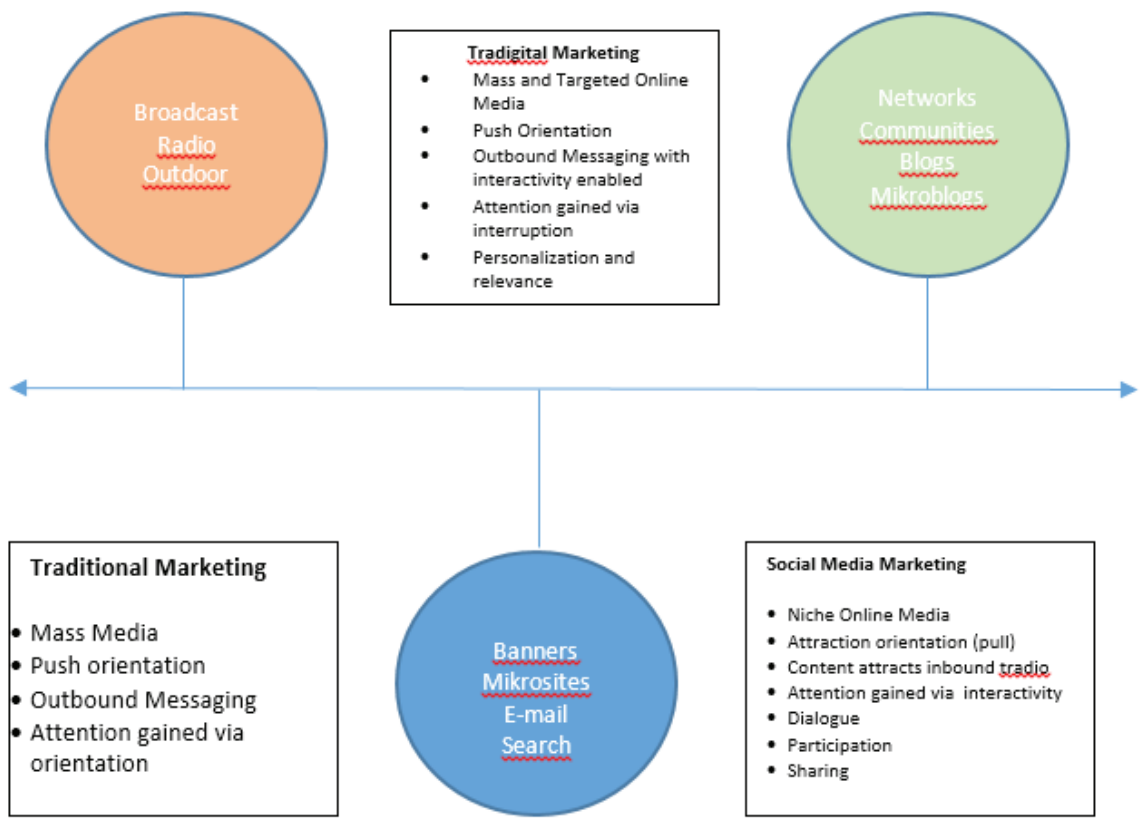

Figure 2: The Evolution of Marketing Communications

Source: Tuten and Solomon, 2015: 127 


\section{TRANSFORMATION OF REAL ESTATE MARKETING}

When the concept of real estate brokers arose, there was no Internet. Brokers controlled all the information. From afar, it was impossible to know almost anything about a property. In addition, there were far fewer ways to advertise properties (Kasanoff, 2014). Whereas with the use of the internet, when buyers can find out the homes they want through online research, an agent has to spend less time touring them around (Depillis, 2013).

A construction company, who created the industry's first online sales platform, gives the opportunity of discussing projects and sales transactions to their customers in the comfort of their homes. The system could be reached by using information management applications, online sales platform application, which allows to communicate with the customer and execute a potential sale, and by clicking online sale icon on the website. The system will allow customers to reach the live sales office with a single click, video calling the sales representative, reviewing projects over articles and last but not least; 360 virtual tours of sample flats (Şahin and Uslu, 2013: 51).

Figure 3 emphasizes The Use of Social Networks in Real Estate Marketing. Even real estate marketing services set up and manage social media accounts for the companies operating on this area (Standard Marketing, 2017).

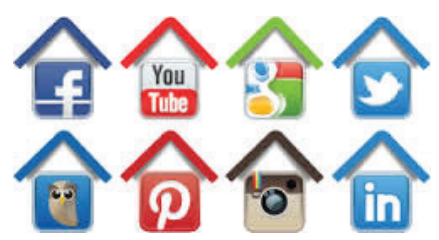

Figure 3: The Use of Social Networks in Real Estate Marketing Source: Standard Marketing. Real Estate Marketing. Social Media Management for Real Estate Agents. http://www.standardmarketing.com/real-estate-marketing-experts/ Retrieved: 14.03.2017.

According to Hubspot's 2015 Social Media Benchmarks Report, the average number of Facebook shares published by companies in the real estate industry in a week is 14 . The real estate industry loves Facebook, as companies in the industry post to Facebook two times per day on average. The companies in the real estate industry tweet 5.61 times per week on average. The real estate industry posts more than any other industry in the report. Another way real estate's high posting frequency is represented in the data: only $28 \%$ of companies post less than once per week across all of their social networks. That's the lowest of any industry. One-third (33.33\%) of the real estate companies in the report have between 5 thousand and 25 thousand social followers across all social networks. $28.21 \%$ fall within the 25 thousandand 100 thousand-follower range. Average number of interactions per posts, (number of 
post the companies published per week), <1 post: $4.49,1-3$ posts: $1.83,3-10$ posts: 1.08 , and 10+ posts: 1.0 (Social Media Benchmarks Report, 2015:10-13-14-15-25-39).

\section{RESEARCH}

\section{IV.1. The Purpose of Research}

While the new media change our daily life practices, it also causes some transformations in the field of marketing. Today it can be said that the real estate sector is also inevitably affected by this transformation and that it has developed new business models that include social media. The purpose of this study is; In the framework of sampling, to investigate the social media's place in real estate marketing with the determined metrics and to discuss the findings by revealing possible dimensions of transformation.

\section{IV.2. The Importance of Research}

In this research, "What are the social networks that the web sites in the sample group direct from the pages of the users?" "Facebook, Twitter, YouTube, Instagram etc. Are the Alexa value sequences overlapping with the metrics of the networks? "The search for the answers to the basic questions has been sought and the findings have also been examined comparatively. In this way, the role of the effective use of social networks in real estate marketing can be determined and the results of the transformation can be evaluated.

\section{IV.3. Method}

Research approaches can be categorized in two groups as "instant (photo)" and "continuous (video)" in terms of the period covered. Whether the researcher is designing an experiment, a questionnaire or a case study, he has to decide whether to answer the research questions by pulling the photograph of the mature or the video (Altunışık et al., 2010: 67). In this research, an instant situation assessment was planned for "determining the role of social media in real estate marketing" and a photograph related to this was taken. In addition, tracing and content analysis methods were used in qualitative analysis techniques. The tracer assists in reaching effective key information sources that make data sampling and sampling more meaningful in research. Content analysis is a technique used to characterize and compare data (Altunışık et al., 2010: 322). The data obtained from the related web sites and social networks were obtained by means of tracing method within the scope of the research and the databases created in this way were compared.

\section{IV.4. Sample}

The ranking evaluation of the web site Alexa.com has been used to construct the sample of the researcher. Alexa is a website run by amazon.com, which displays web traffic on a 
world and country basis. In this way, businesses can continuously monitor the visitor performance of their website. As of 21.12.2016, the sample of the researcher has created the first 5 real estate web sites determined by Alexa.com. Table 1 shows the rankings of these real estate websites Alexa in Turkey.

Table 1: Real Estate Sites in First Bite According to Ranking of Alexa in Turkey

\begin{tabular}{|l|c|}
\hline Real Estate Web Site & Alexa Rating Order \\
\hline sahibinden.com & 8 \\
\hline hurriyetemlak.com & 166 \\
\hline zingat.com & 852 \\
\hline remax.com.tr & 3.438 \\
\hline kacmazemlak.com & 9.969 \\
\hline
\end{tabular}

In Figure 4-5-6-7-8, performance charts of the last year of these web sites are given. As you can see, while the first 4 real estate web sites showed a declining trend towards the end of the year, the site of kacmazemlak.com rises, meaning that the visitor traffic has increased.

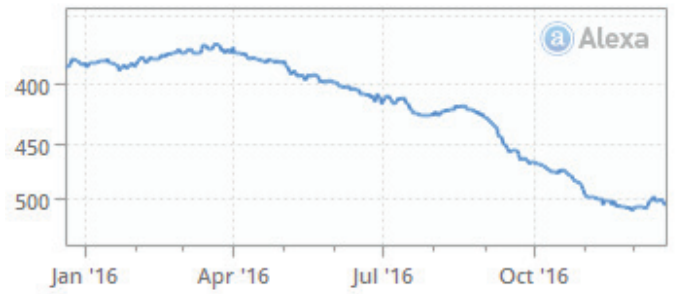

Figure 4: sahibinden.com - Real Estate Web Site’s Visitors Traffic for 2016

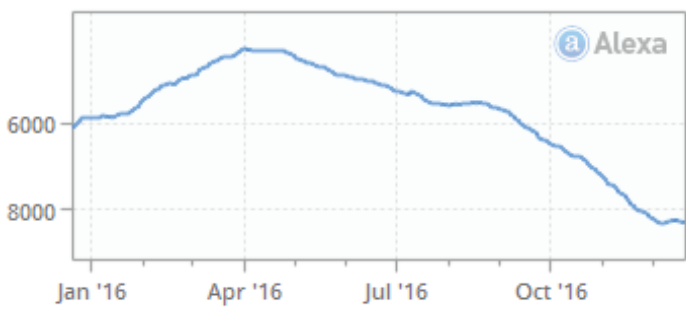

Figure 5: hurriyetemlak.com - Real Estate Web Site’s Visitors Traffic for 2016 


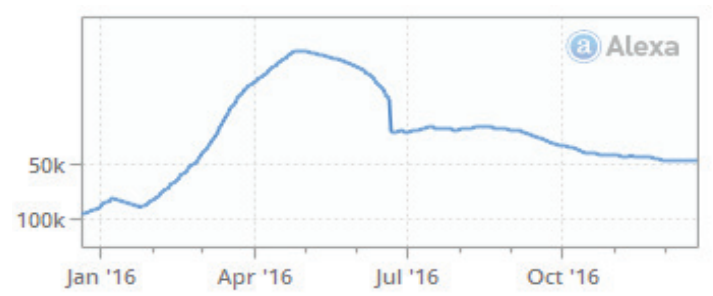

Figure 6: zingat.com Real Estate Web Site's Visitors Traffic for 2016

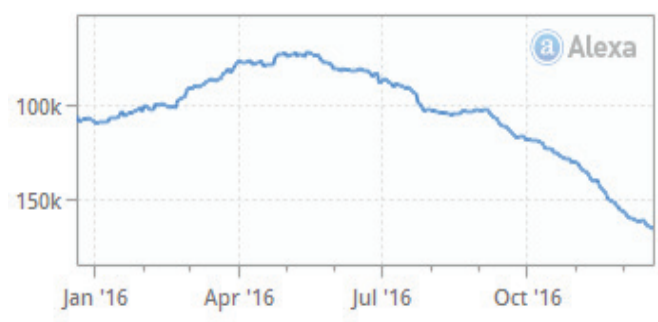

Figure 7: remax.com.tr Real Estate Web Site's Visitors Traffic for 2016

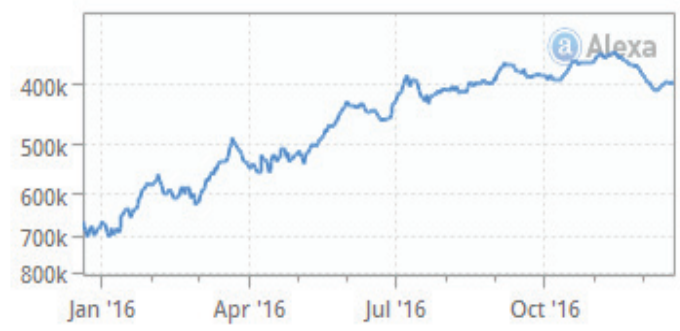

Figure 8: kacmazemlak.com Real Estate Web Site’s Visitors Traffic for 2016

\section{IV.5. Data Collection Tools}

Social media measurement tools were used as data collection tools. These are tools like BuzzSumo, and Retweet Rank. Some of the data is obtained by tracing through the real estate web sites and pages that are directed from them on social networks. It has also benefited from the search engines of social networks. For this reason, the data of this study are secondary data. 


\section{IV.6. Operation}

There have been many studies on which data should be collected/analyzed and which social media these data should be collected from. One of these studies belong to Hoffmand and Fodor. This study focuses on analyzing coorperations' brand popularity and brand commitment on social media. Table 2 shows the metrics that are organized for social media applications. The tables in the "findings" section of this paper utilizes these metrics.

Table 2: Arranged Measurements for Social Media Applications

\begin{tabular}{|c|c|c|c|}
\hline Social Media Application & Brand Awareness & Brand Engagement & Word of Mouth \\
\hline \multirow{6}{*}{ Blogs } & number of unique visits & number of members & $\begin{array}{l}\text { number of references to blog } \\
\text { in other media }\end{array}$ \\
\hline & number of return visits & number of rss feed subscribers & number of reblogs \\
\hline & number of times bookmarked & number of comments & $\begin{array}{l}\text { number of times badge } \\
\text { displayed on other sites }\end{array}$ \\
\hline & search ranking & $\begin{array}{l}\text { amount of user generated } \\
\text { content }\end{array}$ & number of likes \\
\hline & & average length of time on site & \\
\hline & & $\begin{array}{l}\text { number of responses to polis, } \\
\text { contests, surveys }\end{array}$ & \\
\hline \multirow{3}{*}{ Microblogging (e.g. Twitter) } & $\begin{array}{l}\text { number of tweets about the } \\
\text { brand }\end{array}$ & number of followers & number of retweets \\
\hline & valence of tweets $+/$ - & number of replies & \\
\hline & number of followers & & \\
\hline $\begin{array}{l}\text { Cocreation } \\
\text { (e.g. nikeid) }\end{array}$ & number of visits & number of creation attempts & $\begin{array}{l}\text { number of references to } \\
\text { project in other media }\end{array}$ \\
\hline Social bookmarking & number of tags & number of followers & number of additional taggers \\
\hline \multirow{6}{*}{$\begin{array}{l}\text { Forums and discussion } \\
\text { boards } \\
\text { (e.g. Google groups) }\end{array}$} & number of page views & $\begin{array}{l}\text { number of relevant topics/ } \\
\text { threads }\end{array}$ & incoming links \\
\hline & number of visits & number of individual replies & citations in other sites \\
\hline & valence of posted content $+/$ - & number of sign-ups & tagging in social bookmarking \\
\hline & & & $\begin{array}{l}\text { offline references to the forum } \\
\text { or its members }\end{array}$ \\
\hline & & & $\begin{array}{l}\text { in private communities; } \\
\text { number of pieces of content; } \\
\text { chapter pointing to the } \\
\text { community outside of its gates }\end{array}$ \\
\hline & & & number of likes \\
\hline
\end{tabular}




\begin{tabular}{|c|c|c|c|}
\hline \multirow{6}{*}{$\begin{array}{l}\text { Product reviews (e.g. } \\
\text { Amazon) }\end{array}$} & number of reviews posted & length of reviews & number of reviews posted \\
\hline & valence of reviews & relevance of reviews & valence of reviews \\
\hline & $\begin{array}{l}\text { number and valence of other } \\
\text { users' responses to reviews }+/ \text { - }\end{array}$ & $\begin{array}{l}\text { valence of other users' ratings } \\
\text { of reviews }\end{array}$ & $\begin{array}{l}\text { number and valence of other } \\
\text { users' responses to reviews }+/ \text { - }\end{array}$ \\
\hline & number of wish list adds & number of wish list adds & $\begin{array}{l}\text { number of references to } \\
\text { reviews in other sites }\end{array}$ \\
\hline & $\begin{array}{l}\text { number of times product } \\
\text { included in users' lists }\end{array}$ & $\begin{array}{l}\text { overall number of reviewer } \\
\text { rating scores entered }\end{array}$ & $\begin{array}{l}\text { number of visits to review } \\
\text { site page }\end{array}$ \\
\hline & & average reviewer rating score & $\begin{array}{l}\text { number of times product } \\
\text { included in users' lists }\end{array}$ \\
\hline \multirow{7}{*}{$\begin{array}{l}\text { Social networks } \\
\text { (e.g. Facebook, linkedin) }\end{array}$} & number of members/fans & number of comments & $\begin{array}{l}\text { frequency of appearances in } \\
\text { timeline of friends }\end{array}$ \\
\hline & $\begin{array}{l}\text { number of installs of } \\
\text { applications }\end{array}$ & number of active users & number of posts on wall \\
\hline & number of impressions & $\begin{array}{l}\text { number of likes on friends' } \\
\text { feeds }\end{array}$ & number of reposts/shares \\
\hline & number of bookmarks & $\begin{array}{l}\text { number of user-generated } \\
\text { items }\end{array}$ & $\begin{array}{l}\text { number of responses to friend } \\
\text { referral invites }\end{array}$ \\
\hline & $\begin{array}{l}\text { number of reviews/ratings and } \\
\text { valence }+/ \text { - }\end{array}$ & $\begin{array}{l}\text { usage metrics of applications/ } \\
\text { widgets }\end{array}$ & \\
\hline & & $\begin{array}{l}\text { impressions-to-interactions } \\
\text { ratio }\end{array}$ & \\
\hline & & rate of activity & \\
\hline \multirow{5}{*}{$\begin{array}{l}\text { Video and photosharing } \\
\text { (e.g. Flickr, YouTube) }\end{array}$} & $\begin{array}{l}\text { number of views of video/ } \\
\text { photo }\end{array}$ & number of replies & number of embedding \\
\hline & $\begin{array}{l}\text { valence of video/photo ratings } \\
+/-\end{array}$ & number of page views & number of incoming links \\
\hline & & number of comments & $\begin{array}{l}\text { number of references in mock- } \\
\text { ups or derived work }\end{array}$ \\
\hline & & number of subscribers & $\begin{array}{l}\text { number of times republished } \\
\text { in other social media and } \\
\text { offline }\end{array}$ \\
\hline & & & number of likes \\
\hline
\end{tabular}

Source: Hoffman and Fodor, 2010: 44

\section{IV.7. Findings}

\section{Social Networks Routed from Home Pages of Real Estate Websites}

As you can see in Table 3, there are 6 social networks that are redirected from pages of real estate websites. Only two of them - Facebook and Twitter - are on the main pages of all real estate websites. The sites ranked first and third in terms of Alexa ranking are the ones that has all social networks. In this case, it can be said that there is a relationship between the site of sahibinden.com being in the first place and having all the social networks. On the other hand, some websites may not be redirected from the main pages, but these web sites 
may be in the relevant network. Hurriyetemlak.com-Instagram relationship can be given as an example. However, there has been no attempt to conduct a separate research on this subject within the limitations of the study.

Table 3: Social Networks Directed by Pages of Real Estate Websites (As of 21.12.2016)

\begin{tabular}{|l|c|c|c|c|c|c|c|}
\hline Real Estate Web Site & Alexa Rank & Facebook & Twitter & Instagram & LinkedIn & Google+ & YouTube \\
\hline sahibinden.com & $\mathbf{1}$ & + & + & + & + & + & + \\
\hline hurriyetemlak.com & 2 & + & + & - & - & + & + \\
\hline zingat.com & 3 & + & + & + & + & + & + \\
\hline remax.com.tr & 4 & + & + & + & + & - & - \\
\hline kacmazemlak.com & 5 & + & + & - & + & + & - \\
\hline
\end{tabular}

\section{Facebook Media Metrics for Real Estate Websites}

In Table 4, there are metrics such as the number of people talking about real estate websites in the Facebook environment, page liking, and page follower numbers. These pages are configured as "Facebook Fan Page" and the number of people who talk about these pages is based on the fact that social media users talk about these pages in the network environment. Today, it is important to talk about a site in the social media. According to this, the most talked about hurriyetemlak.com site. It can be said that this situation is in parallel with the Alexa evaluation, with the content of speech being important. The kacmazemlak.com site is the last in this metric. It can be said that the Facebook environment is not actively used by this site.

Page liking and number of page followers are parallel in all real estate web sites. So, those who like the page are followers, or vice versa.

The site with the most followers, sahibinden.com, is also the website with the most traffic. An explanation of this situation might be a link from the Facebook environment to the main page. In other words, the Facebook social network is a positive contributor to the Alexa appraisal. On the other hand, this real estate website also has iOS and android apps. Therefore, the mobile application issue should be evaluated within this scope.

Table 4: Facebook Environment Metrics for Real Estate Websites (As of 21.12.2016)

\begin{tabular}{|l|c|c|c|c|}
\hline Real Estate Web Site & Alexa Rank & Number of Speakers About & $\begin{array}{c}\text { Number of pages } \\
\text { liked }\end{array}$ & Page Tracker Count \\
\hline sahibinden.com & $\mathbf{1}$ & $\mathbf{3 . 4 0 2}$ & $\mathbf{1 . 3 6 5 . 2 3 0}$ & $\mathbf{1 . 3 3 8 . 6 6 6}$ \\
\hline hurriyetemlak.com & $\mathbf{2}$ & $\mathbf{4 8 . 7 6 9}$ & $\mathbf{2 7 1 . 9 0 0}$ & $\mathbf{2 6 8 . 9 1 2}$ \\
\hline zingat.com & 3 & 7.812 & 65.757 & 65.498 \\
\hline remax.com.tr & 4 & 6.083 & 172.566 & 169.829 \\
\hline kacmazemlak.com & 5 & 1 & 330 & 319 \\
\hline
\end{tabular}




\section{Twitter Environment Metrics for Real Estate Websites}

In Table 5, metrics such as number of tweet, number of followers, number of accounts followed are shown in twitter environment of real estate web sites. The account with the most followers is the account named sahibinden.com, which overlaps with Alexa valuation.

On the other hand, accounts on sahibinden.com, zingat.com and kacmazemlak.com are too few to follow. This shows that the related sites use the twitter environment as a traditional mass communication medium. However, these environments are interactive environments. In this sense, it can be said that the hurriyetemlak.com account has benefited from this interaction feature.

In addition, the number of tweets from sahibinden.com account is much less than the number of followers compared to other accounts. It can be said that, with the Tweet contents being important, this account presents a phenomenological image.

Table 5: Twitter Environment Metrics for Real Estate Websites (As of 21.12.2016)

\begin{tabular}{|l|c|c|c|c|}
\hline Real Estate Web Site & Alexa Rank & Tweet Number & Number of Followers & $\begin{array}{c}\text { Number of Accounts } \\
\text { Tracked }\end{array}$ \\
\hline sahibinden.com & $\mathbf{1}$ & $\mathbf{2 . 7 3 8}$ & $\mathbf{1 8 2 . 1 8 0}$ & $\mathbf{3}$ \\
\hline hurriyetemlak.com & $\mathbf{2}$ & $\mathbf{2 . 2 9 8}$ & $\mathbf{2 1 . 5 9 0}$ & $\mathbf{2 . 6 5 5}$ \\
\hline zingat.com & 3 & 1.598 & 3.458 & 9 \\
\hline remax.com.tr & 4 & 1.437 & 11.832 & 1.033 \\
\hline kacmazemlak.com & 5 & 165 & 84 & 0 \\
\hline
\end{tabular}

\section{YouTube Media Metrics for Real Estate Websites}

In Table 6, real estate websites have metrics such as the number of channel subscribers in the YouTube channel, the number of video views, and so on. The account with the maximum number of channel subscribers is the account named sahibinden.com, which overlaps with Alexa. But on the other hand, this is the oldest real estate site. It joined YouTube in 2010. When assessed this way, although the account last year, zingat.com has a similar number of subscribers with sahibinden.com. In this case, it can be said that the number of videos must be viewed. Video content is another important issue. Content management and measurement framework should be considered.

Kacmazemlak.com does not have a channel on YouTube. There are different ways to add relevant videos to the real estate site. The reason for this situation can be explained by new participation in the athlete. 
Table 6: YouTube Media Metrics for Real Estate Websites (As of 21.12.2016)

\begin{tabular}{|l|c|c|c|c|}
\hline Real Estate Web Site & Alexa Rank & Channel Subscribers & Total Views of Videos & Date Joined YouTube \\
\hline sahibinden.com & $\mathbf{1}$ & $\mathbf{2 . 4 4 8}$ & $\mathbf{6 . 0 9 8 . 1 2 1}$ & August 2010 \\
\hline hurriyetemlak.com & $\mathbf{2}$ & $\mathbf{1 . 4 7 2}$ & $\mathbf{2 . 6 5 6 . 9 3 2}$ & June 2011 \\
\hline zingat.com & 3 & 2.447 & 1.921 .966 & November 2015 \\
\hline remax.com.tr & 4 & 486 & 173.842 & April 2013 \\
\hline kacmazemlak.com & 5 & 0 & 1.295 & September 2016 \\
\hline
\end{tabular}

\section{Real Estate Websites' Google+ Media Metrics}

Table 7 shows the number of followers in the Google + environment of real estate websites. This app is based on finding the best results on the web by enabling sharing of shared things with listed people and other web users on the Google search engine and has been preferred by all realm websites except remax.com. The website with the most followers is hurriyetemlak.com. The app allows anyone who likes anything on the web to be shown and sent to the right people on Google+ when they want to share it.

Table 7: Google+ Media Metrics for Real Estate Websites (As of 21.12.2016)

\begin{tabular}{|l|c|c|}
\hline Real Estate Web Site & Alexa Rank & Number of Google+ Followers \\
\hline sahibinden.com & 1 & 12.874 \\
\hline hurriyetemlak.com & $\mathbf{2}$ & $\mathbf{2 3 7 . 7 7 9}$ \\
\hline zingat.com & 3 & 138 \\
\hline remax.com.tr & 4 & 0 \\
\hline kacmazemlak.com & 5 & 22 \\
\hline
\end{tabular}

\section{Instagram Medium Metrics for Real Estate Websites}

Table 8 shows the number of shipment and follower metrics in the Instagram environment of the real estate web sites. According to Alexa, sahibinden.com, which has the most traffic, is also the account with the most followers at the same time. In contrast, the fact that at least the shipment has been published can be evaluated within the framework of its "phenomenon is an account".

On the other hand, there was no evaluation of the likelihood of their likes on the senders and the positive / negative characteristics of their comments. This is within the scope of the study. Also, the shipping frequency can be considered as a metric. In this regard, a separate determination has not been made. 
Table 8: Instagram Medium Metrics for Real Estate Websites (As of 21.12.2016)

\begin{tabular}{|l|c|c|c|}
\hline Real Estate Web Sites & Alexa Rank & Number of Posts & Number of Followers \\
\hline sahibinden.com & $\mathbf{1}$ & $\mathbf{7 3}$ & $\mathbf{3 2 . 0 6 6}$ \\
\hline hurriyetemlak.com & 2 & 330 & 3.201 \\
\hline zingat.com & 3 & 82 & 1.603 \\
\hline remax.com.tr & 4 & 210 & 12.751 \\
\hline kacmazemlak.com & & 0 & 0 \\
\hline
\end{tabular}

${ }^{*}$ Location based posts have not been evaluated since they are subject matter.

\section{LinkedIn Media Metrics for Real Estate Websites}

Table 9 shows the number of followers in real estate websites' LinkedIn environment. LinkedIn is a social network dedicated to professionals that allows users to communicate and exchange information with other users on a sectoral basis. In this environment, sahibinden.com, which has the most followers, also ranked first in Alexa value. It can be said that this site uses the network effectively with 16.302 followers. There are also companies operating in the real estate sector at sahibinden.com.

Web sites can also share information about the awards they receive on this network. For example, sahibinden.com site has been selected as the "E-Commerce Site of the Year" by Boğaziçi Bilişim Ödülleri. Thus, it can be said that the LinkedIn platform contributes to the online reputation management. On the other hand, hurriyetemlak.com and kacmazemlak. com were not in this network with their corporate identities.

Table 9: LinkedIn Media Metrics for Real Estate Websites (As of 21.12.2016)

\begin{tabular}{|l|c|c|}
\hline Real Estate Web Site & Alexa Rank & Number of Followers \\
\hline sahibinden.com & $\mathbf{1}$ & $\mathbf{1 6 . 3 0 2}$ \\
\hline hurriyetemlak.com & 2 & 0 \\
\hline zingat.com & 3 & 868 \\
\hline remax.com.tr & 4 & 1.345 \\
\hline kacmazemlak.com & 5 & 0 \\
\hline
\end{tabular}

\section{BuzzSumo Media Metrics for Real Estate Websites}

Table 10 shows the metrics for real estate websites in the BuzzSumo environment. BuzzSumo is a metering tool that shows network-based content that is shared most with "key" in 5 social networks. As of 22.12.2016, the most common content in all five networks belongs to sahibinden.com, which is in line with Alexa's first rank. For example, the most popular content on sahibinden.com key is shared 23,000 times in Facebook environment. Table 
10 was obtained in this way. However, again, sahibinden.com has not been included in Table 10 within the framework of the limitations of research on the number of content that 2.

On the other hand, it appears that the content that is shared most in 4 networks is not shared at all on the Pinterest network. There may be several reasons for this situation. For example; the content feature does not fit the picture format, the Pinterest has a relatively small number of users, or the user practices are not very well developed on this network. However, the Pinterest network is a network that can be used effectively in real estate and it needs to add to the homepage redirects of the web sites.

Table 10 has a feature that is inextricably linked to Alexa valuation. This means that the effective use of social networks contributes positively to web traffic.

Table 10: BuzzSumo Media Metrics for Real Estate Websites (As of 21.12.2016)

\begin{tabular}{|l|c|c|c|c|c|c|}
\hline Real Estate Web Site & Alexa Rank & Facebook & Twitter & LinkedIn & Google+ & Pinterest \\
\hline sahibinden.com & $\mathbf{1}$ & $\mathbf{2 3 . 0 0 0}$ & $\mathbf{2 5 0}$ & $\mathbf{1 5 4}$ & $\mathbf{2}$ & $\mathbf{0}$ \\
\hline hurriyetemlak.com & 2 & 4.800 & 26 & 0 & 0 & 0 \\
\hline zingat.com & 3 & 160 & 8 & 106 & 2 & 0 \\
\hline remax.com.tr & 4 & 88 & 1 & 0 & 0 & 0 \\
\hline kacmazemlak.com & 5 & \multicolumn{7}{|l}{ The results are not viewable by BuzzSumo as there is not much data available. } \\
\hline
\end{tabular}

\section{Retweet Rank Medium Metrics of Real Estate Websites}

Table 11 shows the metrics of real estate web sites in the retweet rank environment. Retweet rank is a measurement tool that shows how many times a retrospective tweet has been retweeted by whom. It also specifies the order of an account's Twitter profile. As you can see, sahibinden.com site is the most valuable web site in line with Alexa evaluation.

Table 11: Retweet Rank Medium Metrics for Real Estate Websites (As of 21.12.2016)

\begin{tabular}{|l|c|c|}
\hline Real Estate Web Site & Alexa Rank & Retweet Rank Value \\
\hline sahibinden.com & $\mathbf{1}$ & $\mathbf{3 . 9 5 3}$ \\
\hline hurriyetemlak.com & 2 & 191.739 \\
\hline zingat.com & 3 & 109.015 \\
\hline remax.com.tr & 4 & 397.175 \\
\hline kacmazemlak.com & 5 & 1.062 .820 \\
\hline
\end{tabular}

\section{CONCLUSION}

In this study, the social media industry is investigating the use of social networks and investigating whether there is a relationship between the most traffic websites in the sector in 
Turkey and their social networking metrics, based on the thesis that social media is causing some transformations in the marketing field.

The findings provide a snapshot of the situation. According to this, while sahibinden. com is the site with the highest web traffic in Alexa value, it is also the most active site in terms of all social network (Facebook, Twitter, Instagram, LinkedIn, YouTube) except Google + environment. Therefore, it can be said that the relationship between web traffic and social network metrics is a positive correlation. The finding of positive correlation answers the basic question of the research (Facebook, Twitter, YouTube, Instagram etc. Are the Alexa value sequences overlapping with the metrics of the networks?). In addition, effective social networking also contributes to search engine optimization. In other words, effective use of networks also supports increasing web traffic.

From these findings, it can be said that the real estate industry has developed new business models that include social media. The marketing approach that started with the industrial revolution is now evolving to consumer focus instead of production focus. The environment we call social media also provides a favorable ground for this new structure.

On the other hand, real estate marketing is excluded from the scope of the limitations of mobility. Social networks, on the other hand, are mobile intensive environments. For this reason, it may be possible to identify correlations that include mobility for future studies.

The transition from feudalism to capitalism has been realized through the industrial revolution. Now it is foreseen that we have experienced the period of digital capitalism with the information revolution. It appears that some major changes in the nature of revolution, such as land ownership or capital ownership, are transforming systems.

\section{References}

Altunışık, R., Coşkun, R., Bayraktaroğlu, S. and Yıldırım, E. (2010). “Sosyal Bilimlerde Araştırma Yöntemleri”. Sakarya: Sakarya Yayıncılık.

Dan, Z. (2010). “The Social Media Marketing Book”. Canada: O’reilly Media. http://danzarrella. com/Social_Media_Marketing_Book_ch1_3.pdf Retrieved: 07.03.2017.

Depillis, L. (2013). "Why do real estate agents still exist?". The Washington Post. https://www. washingtonpost.com/news/wonk/wp/2013/08/22/why-do-real-estate-agents-stillexist/?utm_term=.3fa5e6c8949c Retrieved: 07.03.2017.

Evans, L. (2010). “Social Media Marketing”. United State of America: Que Publishing.

Facebook. Facebook Business (2017).

Felix, R., Rauschnabel, P.A., and Hinsch, C. (2017). “Elements of Strategic Social Media Marketing: A Holistic Framework”. Journal of Business Research. 70. pp.118-126. 
Filieri, R. (2015). "What makes online reviews helpful? A diagnosticity-adoption framework to explain informational and normative influences in e-WOM". Journal of Business Research. 68(6). pp.1261-1270.

Hoffman, D. L., and Fodor, M. (2010). „Can you measure the ROI of your social media marketing?”. MIT Sloan Management Review. 52(1). pp.41-49.

Kasanoff, B. (2014). "Are Real Estate Brokers Obsolete?" https://www.forbes.com/sites/ brucekasanoff/2014/04/04/real-estate-brokers-obsolete/\#226154a27953 Retrieved: 07.03.2017.

Kim, A.J. and Ko, E. (2012). "Do social media marketing activities enhance customer equity? An empirical study of luxury fashion brand". Journal of Business Research. 65(10). pp.14801486.

Neti, S. (2011). "Social Media and Its Role in Marketing". International Journal of Enterprise Computing and Business Systems. 1(2). pp.1-16.

Saravanakumar, M. and Suganthalakshmi, T. (2012). "Social Media Marketing”. Life Science Journal. 9(4). pp.4444 - 4451.

Social Media Benchmarks Report. (2015). Hubspot. https://cdn2.hubspot.net/hub/53/ file-2415418647-pdf/00-OFFERS-HIDDEN/social-media-benchmarks-2015. pdf?t=1489501581342 Retrieved: 14.03.2017.

Standard Marketing. Real Estate Marketing. Social Media Management for Real Estate Agents. http://www.standardmarketing.com/real-estate-marketing-experts/ Retrieved: 14.03.2017.

Stelzner, M.A. (2016). “Social Media Marketing Industry Report”. How Marketers Are Using Social Media to Grow Their Businesses. Social Media Examiner Publishing. pp.1-57.

Şahin, D. and Uslu, T. (2013). "Bilgi Yönetiminin İnşaat ve Emlak Sektöründeki Dönüşüme Etkisinin İncelenmesi”. Bilgi Ekonomisi ve Yönetimi Dergisi. 8(2). pp.41-58.

The National Association of Realtors and Google. (2012). "The Digital House Hunt: Consumer and Market Trends in Real Estate”. pp.1-28.

Tuten, T.L. and Solomon, M.R. (2015). "Social Media Marketing”. Thousand Oaks, CA: Sage Publications.

Twitter. Twitter for Business (2017).

Weinberg, T. (2009). “The new community rules: Marketing on the social Web”. Sebastopol, CA: O’Reilly Media Inc. 


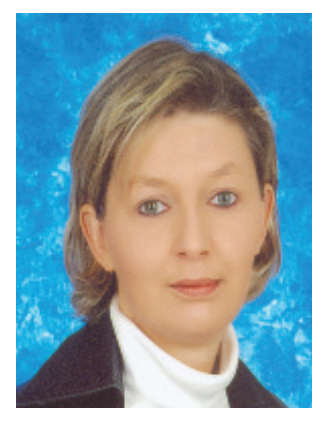

Çiğdem AYTEKINN - cigdem.aytekin@marmara.edu.tr

Graduated from Uludağ University Faculty of Engineering, Department of Electronics Engineering in 1991. Completed MSc in Marmara University, Institute for Graduate Studies in Pure and Applied Sciences, Electronics Computer Education, Electronics - Communication Education via thesis Digital Education Platform via Satellite and PhD Marmara University, Institute of Social Sciences, Communication Sciences, Information Systems via thesis Opinion Mining on Blogs for Customer Relationship Management. Now working as Associate Professor Marmara University Faculty of Engineering. Has national and international publications based on Web 2.0 applications such as; video sharing websites, platform of Facebook, Wiki applications, Podcasting, Blogs. Text Mining, Natural Language Processing, Opinion Mining, Text Classification Techniques and Web Mining are in of her academic sphere of interests.

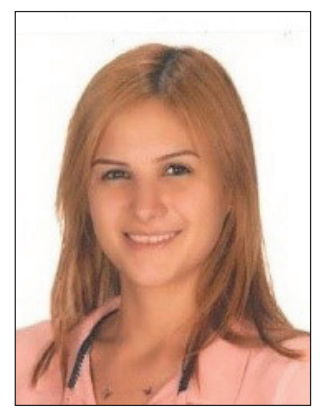

Seray Merve KESKINN DEMİRLI - seraymerve@gmail.com

Graduated from Ylldiz Technical University, Department of Civil Engineering in 2012. Completed MSc in Maltepe University, Institute of Social Science, Business Administration via project "The Role of Social Media In Real Estate Marketing: A Research On The Transformation Of Real Estate". Now working as a Design Office Engineer in a multi-national company. Social media marketing is number one in her academic interest, which is desired to be continued along with her first project. 
